\title{
MOTIVASI BELAJAR SISWA DALAM PEMBELAJARAN FISIKA
}

\author{
Dina Selvia \\ Universitas Sultan Ageng Tirtayasa \\ nadinaaa02@gmail.com
}

\begin{abstract}
The purpose of this study was to describe the motivation to learn physics in class X MIA at SMAN 9 Jambi City. This type of research is descriptive research with a quantitative approach. The population of this study were students of class X MIA at SMAN 9 Jambi City. The sampling technique in this research is total sampling. The research instrument used was a questionnaire on students' motivation to learn physics. The data analysis technique used is quantitative analysis using descriptive statistics. The results of this study indicate that the motivation to learn physics in class X MIA at SMAN 9 Jambi City on the intrinsic motivation dimension is in the high category with a percentage of 59,80\% where students' attitudes are in the frequent category and the extrinsic motivation dimension is in the high category with a percentage of 61,76\% where students' attitudes are in the frequent category. Conclusions, that the attitudes of respondents on the intrinsic motivation dimension include indicators of high learning activities tend to be in the occasional category, indicators of perseverance in doing assignments tend to be in the frequent category, and tenacious indicators in facing difficulties tend to be are in the frequent category. In the extrinsic motivation dimension, indicators of the presence of information from teachers tend to be in the always category, indicators of feedback tend to be in the frequent category, and indicators of reinforcement tend to be in the frequent category.
\end{abstract}

Keywords: Learning Motivation, Physics, Intrinsic and Extrinsic Method

Abstrak: Tujuan penelitian ini adalah untuk mendeskripsikan motivasi belajar fisika siswa kelas X MIA di SMAN 9 Kota Jambi. Jenis penelitian ini adalah penelitian deskriptif dengan pendekatan kuantitatif. Populasi penelitian ini adalah siswa kelas X MIA di SMAN 9 Kota Jambi. Teknik pengambilan sampel dalam penelitian ini adalah total sampling. Instrumen penelitian yang digunakan adalah angket motivasi belajar fisika siswa. Teknik analisis data yang digunakan adalah analisis kuantitatif menggunakan statistik deskriptif. Hasil penelitian ini menunjukkan bahwa motivasi belajar fisika siswa kelas X MIA di SMAN 9 Kota Jambi pada dimensi motivasi intrinsik berada pada kategori tinggi dengan persentase 59,80\% dimana sikap siswa berada pada kategori sering dan pada dimensi motivasi ekstrinsik berada pada kategori tinggi dengan persentase 61,76\% dimana sikap siswa berada pada kategori sering Simpulan, bahwa sikap responden pada dimensi motivasi intrinsik meliputi indikator aktivitas belajar tinggi cenderung berada pada kategori kadang-kadang, indikator tekun dalam mengerjakan tugas cenderung berada pada kategori sering, dan indikator ulet dalam menghadapi kesulitan cenderung berada pada kategori sering. Pada dimensi motivasi ekstrinsik meliputi indikator adanya informasi dari guru cenderung berada pada kategori selalu, indikator adanya umpan balik cenderung berada pada kategori sering, dan indikator adanya penguatan cenderung berada pada kategori sering.

Kata kunci: Motivasi Belajar, Fisika, Metode Intrinsik dan Ekstrinsik

\section{PENDAHULUAN}

Pendidikan berfungsi untuk mengembangkan kemampuan dan membentuk karakter serta peradaban bangsa yang bermartabat dalam mencerdaskan kehidupan bangsa. Fisika dapat di artikan sebagai ilmu yang mempelajari tentang kejadian-kejadian alam yang bersifat fisik dan dapat dipelajari secara pengamatan, eksperimen dan teori. Hasil-hasil fisika dapat dinyatakan dalam bentuk fakta, konsep, prinsip, hukum dan teori. Ilmu fisika dibelajarkan melalui kegiatan pembelajaran di sekolah melalui kegiatan pembelajaran di sekolah melalui serangkaian kegiatan yang dirancang untuk mendukung proses belajar siswa yang bersifat internal (Suparwoto, 2007).

Pendidikan identik dengan proses belajar. Dimana pendidikan identik dengan proses belajar. Proses belajar menghasilkan suatu perubahan dalam diri individu yang menyangkut perubahan dalam beberapa aspek. Perubahan perilaku dalam belajar mencakup tiga ranah seperti yang dinyatakan oleh Bloom et al., (1956) yaitu ranah kognitif, ranah afektif, dan ranah psikomotor. Dengan demikian, seseorang dikatakan mengalami proses belajar jika terdapat peningkatan perilaku dalam hal kognitif, afektif dan psikomotor dalam diri orang tersebut. Belajar merupakan 
suatuproses perubahan dalam diri individu yang menghasilkan perubahan tingkah laku karena hasil interaksi dari sesama maupun lingkungan berdasarkan praktik dan pengalaman tertentu (Uno, 2008).

Pembelajaran karakter memerlukan terobosan dalam menginovasi strategi dan metode pembelajaran yang akan dipakai mengingat munculnya berbagai fenomena baru yang yang sebelumnya tidak ada (Nuri, 2012). Faktor-faktor yang mempengaruhi proses belajar siswa dalam bidang sains berasal dari dalam diri siswa dan guru. Faktor yang berasal dari siswa termasuk ke dalam kelompok faktor internal, meliputi motivasi belajar sains, faktor ketertarikan siswa terhadap pelajaran fisika, faktor orientasi atau tujuan belajar siswa, dan faktor keinginan siswa untuk lebih mempelajari alam. Faktor guru yang terangkum dalam faktor eksternal antara lain kurikulum, interaksi guru dengan siswa dana model pembelajaran yang diterapkan oleh guru.

Salah satu faktor internal yang berpengaruh terhadap proses belajar siswa dalam mempelajari ilmu fisika yaitu motivasi. Motivasi merupakan salah satu faktor yang berpengaruh terhadap kegiatan yang sedang dijalankan oleh seorang individu. Motivasi belajar siswa dapat diukur menggunakan instrumen yang dikembangkan berdasarkan aspek-aspek dari motivasi belajar. Keller (1987) mengembangkan aspek-aspek yang dapat digunakan untuk mengukur tingkat motivasi belajar siswa yang dinamakan ARCS (Attention Relevance Confidence Satisfaction).

Penelitian dari Cicuto \& Torres (2016) menguatkan bahwa lingkungan belajar yang aktif dapat memotivasi siswa untuk lebih belajar dengan keras. Lingkungan belajar yang aktif didukung oleh proses pembelajaran yang aktif pula. Penelitian dari Velayutham et al., (2011) mendukung teori yang menyatakan pentingnya tingkat motivasi belajar siswa untuk mata pelajaran Sains. Tantangan awal untuk seorang guru adalah membangkitkan motivasi belajar Sains dari para siswa.
Motivasi belajar Sains merupakan komponen afektif yang sangat penting karena motivasi belajar melandasi proses pengkonsepsian suatu materi, berpikir kritis, strategi dalam belajar, dan keberhasilan dalam belajar. Simpulan penelitian bahwa faktor terakhirlah yang merupakan faktor penentu tingkat prestasi belajar siswa.

Titik berat Fisika untuk pemahaman matematis cenderung membuat siswa beranggapan bahwa Fisika adalah pelajaran yang sulit. Hasil belajar siswa untuk mata pelajaran Fisika tergolong rendah. Berdasarkan data nilai UAS Semester 1 tahun pelajaran 2016/2017 untuk mata pelajaran Fisika dari 3 SMA di Kota Surakarta diperoleh bahwa hanya 40\% dari seluruh siswa kelas XI yang memiliki nilai di atas KKM sebesar 75. Siswa-siswa yang mendapatkan nilai di bawah KKM harus tes kembali atau melaksanakan remediasi agar hasil kognitif dalam mata pelajaran Fisika mencapai ketuntasan. Hasil observasi ketika pembelajaran Fisika ditemukan bahwa kesungguhan sebagian besar siswa dalam belajar Fisika kurang terlihat. Siswa tidak berperan aktif di kelas. Hal tersebut didukung oleh hasil penelitian Rahman (2004) yang mengemukakan bahwa kebanyakan siswa tidak memiliki motivasi belajar yang baik dan sikap positif terhadap pelajaran Fisika. Hal tersebut ditandai dengan tidak adanya kesungguhan siswa dalam belajar Fisika dan kelalaian siswa untuk mengerjakan tugas dari guru Fisika. Akibatnya, hasil belajar Fisika rendah.

Berdasarkan uraian tersebut maka perlu dilakukan kajian mengenai tingkat motivasi belajar siswa dalam mengikuti pembelajaran Fisika di kelas. Hal itu dilandasi oleh faktor motivasi belajar berperan penting dalam proses belajar, dan tingkat motivasi belajar siswa yang telah diketahui dapat dijadikan pedoman guru dalam melaksanakan proses pembelajaran yang lebih baik.

\section{LANDASAN TEORI}

Peningkatan motivasi belajar
merupakan suatu proses, jika ingin


menyelesaikan permasalahan motivasi belajar maka perlu adanya suatu tindakan diproses pembelajaran (Schunk, 2012). Perbaikan dalam proses belajar mengajar dapat dilakukan dengan memberikan motivasi kepada siswa agar dapat mengikuti pembelajaran dengan baik. Karena, motivasi dipandang sebagai dorongan mental yang menggerakkan dan mengarahkan perilaku manusia, termasuk perilaku belajar (Dimyati dan Mudjiono, 2009). Pendapat lain mengenai motivasi belajar juga disampaikan oleh Yamin (2007), yang berbunyi motivasi belajar merupakan daya penggerak psikis dari dalam diri seseorang untuk dapat melakukan kegiatan belajar dan menambah keterampilan dan pengalaman.

ARCS sebagai tingkat untuk mengukur motivasi dikembangkan oleh Keller (1987) didasarkan pada sintesis dari konsep motivasi dan karakteristik motivasi yang dikelompokkan menjadi empat aspek yaitu Attention (Perhatian), Relevance (Relevansi), Confidance (Percaya diri), dan Satisfaction (Kepuasaan). Attention (perhatian) yaitu sikap yang ditunjukkan oleh siswa dengan memberi atensi atau pemfokusan diri terhadap pembelajaran Fisika. perhatian siswa timbul karena rasa ingin tahu. Relevance (relevansi) adalah pandangan siswa tentang keterkaitan antara manfaat dan aplikasinya pada kehidupan sehari-hari. Motivasi belajar siswa akan terjaga apabila siswa dapat menemukan hubungan antara apa yang dipelajari dengan manfaatnya dalam memenuhi kebutuhan pribadi maupun sesuai dengan nilai yang diyakini. Confidence (percaya diri) adalah keyakinan diri siswa dalam belajar Fisika dan menyelesaikan masalah Fisika. siswa yang memiliki rasa bahwa dirinya berkompeten atau mampu dalam belajar Fisika, maka keinginan untuk belajar Fisika semakin baik. Satisfaction (kepuasan) yaitu rasa puas dari dalam diri siswa dalam memecahkan permasalahan Fisika yang sedang dipelajari.

\section{METODE PENELITIAN}

Tempat penelitian adalah SMAN 9 Kota Jambi yang terletak di Jalan Berdikari Kelurahan Payo Selincah Kecamatan Paal Merah. Penelitian dilakukan di kelas X MIA yaitu di kelas X MIA 1, X MIA 2, dan $X$ MIA 3. Desain Penelitian Jenis penelitian ini adalah penelitian deskriptif pada penelitian ini peneliti mendeskripsikan motivasi belajar fisika siswa kelas X MIA di SMAN 9 Kota Jambi pada dimensi motivasi intrinsik dan pada dimensi motivasi ekstrinsik. Peneliti menghimpun fakta tentang motivasi belajar fisika siswa menggunakan angket motivasi belajar fisika siswa. Sehingga, diperoleh data kuantitatif yang perlu dianalisis untuk menghasilkan informasi. Populasi dalam penelitian ini adalah seluruh siswa kelas $\mathrm{X}$ MIA di SMAN 9 Kota Jambi, sebagaimana pada Tabel 1. Peneliti menggunakan teknik pengambilan sampel yaitu total sampling. Peneliti menggunakan total berlaku untuk populasi yaitu siswa kelas $\mathrm{X}$ MIA di SMAN 9 Kota Jambi.

Tabel 1.

Populasi Siswa Kelas X MIA di SMAN 9 Kota Jambi

\begin{tabular}{cc}
\hline Nama Kelas & Jumlah Siswa \\
\hline X MIA 1 & 34 \\
\hline X MIA 2 & 34 \\
\hline X MIA 3 & 34 \\
\hline Jumlah siswa & 102 \\
\hline
\end{tabular}

Data yang diperlukan adalah data primer. Data primer yang diperoleh berupa data motivasi belajar fisika siswa yang diambil dengan menggunakan instrumen penelitian berupa angket. Instrumen Penelitian Peneliti menggunakan indikator motivasi belajar yang dinyatakan oleh Ekawarna (2009) dan telah dikembangkan menjadi angket motivasi belajar fisika siswa oleh Nababan (2014) yang terdiri dari 25 item pernyataan. Setiap Ijen pernyataan dinilai dengan skala likert. Adapun kisi-kisi angket motivasi belajar fisika siswa terlihat pada Tabel 2. 
Tabel 2.

Kisi-Kisi Angket Motivasi Belajar Fisika Siswa

\begin{tabular}{|c|c|c|c|c|}
\hline Dimensi & Indikator & Deskripsi & No Butir & Jumlah \\
\hline Motivasi & Aktivitas belajar yang tinggi & a. Bekerja mandiri & 1 & 1 \\
\hline \multirow[t]{13}{*}{ intrinsik } & & b. Belajar diluar waktu sekolah & 2 & 1 \\
\hline & & c. Penyusunan waktu belajar & 3 & 1 \\
\hline & & $\begin{array}{l}\text { d. Mengulang pelajaran } \\
\text { dirumah }\end{array}$ & 4 & 1 \\
\hline & \multirow[t]{6}{*}{ Tekun dalam mengerjakan tugas } & $\begin{array}{l}\text { a. Mencari bahan atau sumber } \\
\text { bacaan }\end{array}$ & 5 & 1 \\
\hline & & b. Memeriksa kelengkapan & 6 & 1 \\
\hline & & tugas & 7 & 1 \\
\hline & & c. Tidak mudah bosan & 8 & 1 \\
\hline & & d. Memperbaiki tugas & 9 & 1 \\
\hline & & e. Terus bekerja & & \\
\hline & \multirow[t]{4}{*}{ Ulet dalam menghadapi ujian } & $\begin{array}{l}\text { a. Mengajukan pertanyaan } \\
\text { pada guru }\end{array}$ & 10 & 1 \\
\hline & & b. Bertanya pada teman & $11-12$ & 2 \\
\hline & & c. Belajar bersama & 13 & 1 \\
\hline & & d. Diskusi & 14 & 1 \\
\hline Motivasi & \multirow[t]{3}{*}{ Adanya informasi guru } & a. Memberi tujuan belajar & 15 & 1 \\
\hline \multirow[t]{7}{*}{ Ekstrinsik } & & b. Menjelaskan melalui contoh & 16 & 1 \\
\hline & & $\begin{array}{l}\text { c. Menulis hal-hal yang } \\
\text { dianggap penting }\end{array}$ & 17 & 1 \\
\hline & \multirow[t]{3}{*}{ Adanya umpan balik } & $\begin{array}{l}\text { a. Memberi informasi hasil } \\
\text { ulangan }\end{array}$ & $18-20$ & 3 \\
\hline & & $\begin{array}{l}\text { b. Memberi komentar terhadap } \\
\text { tugas latihan/PR }\end{array}$ & 21 & 1 \\
\hline & & $\begin{array}{l}\text { c. Memberi kesempatan } \\
\text { bertanya }\end{array}$ & $22-23$ & 2 \\
\hline & \multirow[t]{2}{*}{ Adanya penguatan } & a. Memberikan pujian & 24 & 1 \\
\hline & & $\begin{array}{l}\text { b. Membantu menemukan } \\
\text { cara-cara menarik } \\
\text { kesimpulan }\end{array}$ & 25 & 1 \\
\hline
\end{tabular}

Sumber: Diadopsi dari Nababan (2014)

Setelah data dari seluruh responden terkumpul, peneliti menggunakan tabel pemindahan untuk distribusi penskoran angket. Pada tabel pemindahan dilakukan proses kuantifikasi untuk mengkonversikan data kualitatif menjadi data kuantitatif. Peneliti menggunakan model lima pilihan, yang dituliskan pada Tabel 3 .

Tabel 3.

Penskoran Alternatif Respon

\begin{tabular}{cc}
\hline Alternatif respon & Skor \\
\hline Selalu & 5 \\
\hline Sering & 4 \\
\hline Kadang-kadang & 3 \\
\hline Jarang & 2 \\
\hline Tidak pernah & 1 \\
\hline
\end{tabular}

Kedua, menganalisis data yaitu peneliti menganalisis data untuk melakukan perhitungan skor maksimal, skor minimal, mean, standar deviasi, dan persentase kategori motivasi belajar fisika siswa. Analisis data dilakukan dengan menggunakan Microsoft Excel dan rumus manual. Teknik analisis data penelitian ini adalah analisis kuantitatif dengan menggunakan statistik deskriptif. Penarikan kesimpulan pada statistik deskriptif hanya ditujukan pada kumpulan data yang ada. Statistik deskriptif yang digunakan adalah ukuran pemusatan yaitu mean, ukuran penyebaran yaitu standar deviasi, dan persentase kategori.

Mean dirumuskan pada Persamaan (1).

$$
\sum=\frac{\Sigma f \cdot x}{\Sigma f}
$$


Keterangan:

$X^{-}=$mean

$X=$ data

$f=$ frekuensi data

Standar deviasi dirumuskan pada Persamaan (2).

$$
s=\sqrt{\frac{\sum f\left(x-x_{\text {mutlak })^{2}}\right.}{n}}
$$

Keterangan :

$$
\begin{aligned}
& s^{2}=\text { varian } \\
& s=\text { standar deviasi } \\
& (X-X)^{2}=\text { kuadrat simpangan } \\
& \mathrm{n}=\text { banyak data } \\
& f=\text { frekuensi data }
\end{aligned}
$$

Analisis data yang diperoleh dari angket dapat didasarkan pada rerata skor jawaban responden, maka skor yang terkumpul dapat dikategorikan berskala interval. Untuk menentukan jarak interval digunakan Persamaan (3).

$$
i=\frac{\text { skor terting gi-skor terendah }}{\text { jumlah kelas interval }}
$$

Keterangan:

$\mathrm{i}=$ jarak interval

Sehingga dapat disusun tabel kategori sikap responden pada indikator pernyataan angket, berdasarkan rerata skor jawaban responden yang digunakan seperti pada Tabel 4 dan juga dapat disusun tabel kategori motivasi belajar fisika siswa, berdasarkan rerata skor jawaban responden yang digunakan seperti pada Tabel 5.
Tabel 4.

Kategori Sikap Responden pada Indikator Pernyataan

\begin{tabular}{ccc}
\hline No. & Interval Rerata Skor & Kategori \\
\hline 1 & $4,21 \leq X^{-} \leq 5,0$ & Selalu (SL) \\
\hline 2 & $3,41 \leq X^{-} \leq 4,2$ & Sering (SR) \\
\hline 3 & $2,61 \leq X^{-} \leq 3,4$ & Kadang-Kadang (KK) \\
\hline 4 & $1,81 \leq X^{-} \leq 2,6$ & Jarang (JR) \\
\hline 5 & $1,0 \leq X^{-} \leq 1,8$ & Tidak Pernah (TP) \\
\hline Sumber: Widoyoko &
\end{tabular}

Tabel 5.

Kategori Motivasi Belajar Fisika Siswa

\begin{tabular}{ccc}
\hline No. & Interval Retata Skor & Katagori \\
\hline 1 & $4,21 \leq X^{-} \leq 5,0$ & Sangat Tinggi (ST) \\
\hline 2 & $3,41 \leq X^{-} \leq 4,2$ & Tinggi (T) \\
\hline 3 & $2,61 \leq X^{-} \leq 3,4$ & Sedang (S) \\
\hline 4 & $1,81 \leq X^{-} \leq 2,6$ & Rendah (R) \\
\hline 5 & $1,0 \leq X^{-} \leq 1,8$ & Sangat Rendah (SR) \\
\hline
\end{tabular}

Sumber: Widoyoko

Untuk mencari persentase kategori motivasi belajar digunakan Persamaan (4).

$\%$ kategori $=\frac{\text { frekuensi } \text { kategori }}{\text { jumlah responden }} \times 100 \%$

Ketiga, menyajikan data dalam bentuk tabel atau grafik. Keempat, menginterpretasikan data.

\section{HASIL PENELITIAN}

Data diperoleh dari hasil sebaran angket kepada 102 siswa SMAN 9 Kota Jambi. Berikut data hasil yang diperoleh dari penyebaran angket motivasi belajar fisika siswa pada Tabel 6 .

Tabel 6.

Hasil Analisis Statistik Deskriptif

\begin{tabular}{ccccccc}
\hline $\begin{array}{c}\text { Statistik } \\
\text { Deskriptif }\end{array}$ & \multicolumn{3}{c}{ Motivasi Intrinsik } & \multicolumn{3}{c}{ Motivasi Ekstrinsik } \\
\hline & 1 & 2 & 3 & 4 & 5 & 6 \\
\hline Standar Deviasi & 0,63 & 0,54 & 0,56 & 0,55 & 0,54 & 0,86 \\
\hline Skor Max & 5 & 5 & 5 & 5 & 5 & 5 \\
\hline Skor Min & 1,5 & 2 & 2,4 & 3 & 2,17 & 1,5 \\
\hline Mean & 3,06 & 3,87 & 3,77 & 4,22 & 3,82 & 3,89 \\
\hline
\end{tabular}

Keterangan:

Motivasi Intrinsik

1. Indikator aktivitas belajar yang tinggi

2. Indikator tekun dalam mengerjakan tugas

3. Indikator ulet dalam menghadapi kesulitan

Motivasi Ekstrinsik 
5. Indikator adanya informasi dari guru

6. Indikator adanya umpan balik

7. Indikator adanya penguatan

Berdasarkan penggolongan kategori sikap responden dengan skala interval (Tabel 4), nilai Mean pada Tabel 6 menunjukkan bahwa sikap responden pada dimensi motivasi intrinsik meliputi indikator aktivitas belajar tinggi cenderung berada pada kategori kadang-kadang, indikator tekun dalam mengerjakan tugas cenderung berada pada kategori sering, dan indikator ulet dalam menghadapi kesulitan cenderung berada pada kategori sering. Pada dimensi motivasi ekstrinsik meliputi indikator adanya informasi dari guru cenderung berada pada kategori selalu, indikator adanya umpan balik cenderung berada pada kategori sering, dan indikator adanya penguatan cenderung berada pada kategori sering.

\section{PEMBAHASAN}

Permasalahan yang dideskripsikan dalam penelitian ini adalah motivasi belajar fisika siswa kelas X MIA di SMAN 9 Kota Jambi pada dimensi motivasi intrinsik meliputi indikator aktivitas belajar yang tinggi, indikator tekun dalam mengerjakan tugas, dan indikator ulet dalam menghadapi kesulitan. Serta motivasi belajar fisika siswa kelas X MIA di SMA N 9 Kota Jambi pada dimensi motivasi ekstrinsik meliputi indikator adanya informasi dari guru, indikator adanya umpan balik, dan indikator adanya penguatan.

Data diperoleh dari responden yang berjumlah 102 siswa, yang diambil menggunakan teknik pengambilan sampel yaitu total sampling. Total sampling merupakan teknik pengambilan sampel yang menggunakan seluruh anggota populasi (Usman dan Akbar, 2015). Peneliti menggunakan total sampling karena peneliti ingin hasil penelitian berlaku untuk populasi yaitu siswa kelas X MIA di SMAN 9 Kota Jambi. Menurut Arikunto (2013) penelitian populasi dilakukan apabila peneliti ingin melihat semua likuliku yang ada di dalam populasi.
Untuk mengumpulkan data penelitian, peneliti menggunakan instrumen penelitian berupa angket. Angket yang digunakan adalah angket motivasi belajar fisika siswa yang diadopsi dari Nababan (2014), terdiri dari 25 item pernyataan yang dikelompokkan menjadi 14 item pernyataan pada dimensi motivasi intrinsik meliputi 4 item untuk mendeskripsikan indikator aktivitas belajar yang tinggi, 5 item untuk mendeskripsikan indikator tekun dalam mengerjakan tugas, dan 5 item untuk mendeskripsikan indikator ulet dalam menghadapi kesulitan. Serta 11 item pernyataan pada dimensi motivasi ekstrinsik meliputi 3 item untuk mendeskripsikan indikator adanya informasi dari guru, 6 item untuk mendeskripsikan indikator adanya umpan balik, dan 2 item untuk mendeskripsikan indikator adanya penguatan. Data yang diperoleh melalui angket merupakan data kualitatif. Agar dapat dianalisis menggunakan statistik maka dilakukan proses kuantifikasi menggunakan penskoran dengan skala likert, sebagaimana pada Tabel 4. Menurut Sudijono (2008) proses kuantifikasi merupakan proses mengkonversikan data kualitatif menjadi data kuantitatif.

Dilakukan penggolongan kategori motivasi belajar fisika siswa berdasarkan skala interval sebagaimana yang dinyatakan oleh Widoyoko (2014) berdasarkan rerata skor jawaban responden, agar dapat menentukan pengolongan kategori motivasi belajar fisika siswa dan melakukan perhitungan persentase kategori motivasi belajar fisika siswa pada indikator aktivitas belajar yang tinggi, indikator tekun dalam mengerjakan tugas, indikator ulet dalam menghadapi kesulitan, indikator adanya informasi dari guru, indikator adanya umpan balik, dan indikator adanya penguatan.

Berdasarkan hasil penelitian yang diperoleh, tinggi atau rendahnya motivasi 
belajar siswa dapat diukur dari indikator motivasi belajar sebagaimana yang dinyatakan oleh Ekawarna (2009), yaitu pertama, indikator aktivitas belajar yang tinggi Motivasi belajar fisika siswa pada indikator aktivitas belajar yang tinggi cenderung berada pada kategori sedang dengan persentase $47,06 \%$ dimana sikap siswa cenderung berada pada kategori kadang-kadang. Kedua, indikator tekun dalam mengerjakan tugas motivasi belajar fisika siswa pada indikator tekun dalam mengerjakan tugas cenderung berada pada kategori tinggi dengan persentase 59,80\% dimana sikap siswa cenderung berada pada kategori sering. Hasil penelitian ini sejalan dengan yang dinyatakan oleh Hadis dan Nurhayati (2014) bahwa siswa yang memiliki motivasi belajar tinggi menunjukkan sikap dan perilaku belajar yang baik berupa tekun dalam melakukan aktivitas belajar. Bentuk-bentuk sikap dan perilaku yang ditunjukkan siswa yang berada pada kategori motivasi belajar tinggi untuk indikator tekun dalam mengerjakan tugas adalah siswa sering berusaha mencari bahan atau sumber belajar yang dianjurkan guru, siswa sering memeriksa kelengkapan tugas fisika sebelum dikumpulkan, siswa sering tidak mudah bosan jika belajar tentang mata pelajaran fisika, siswa sering berusaha memperbaiki tugas fisika yang diberikan guru jika tugas tersebut salah, siswa sering akan terus bekerja menyelesaikan tugas atau PR fisika yang diberikan guru sampai benar-benar sempurna.

Ketiga, indikator ulet dalam menghadapi kesulitan, Motivasi belajar fisika siswa pada indikator ulet dalam menghadapi kesulitan cenderung berada pada kategori tinggi dengan persentase 50\% dimana sikap siswa cenderung berada pada kategori sering. Hasil penelitian ini sejalan dengan yang dinyatakan oleh Hadis dan Nurhayati (2014) bahwa siswa yang memiliki motivasi belajar tinggi menunjukkan sikap dan perilaku belajar yang baik berupa ulet dalam melakukan aktivitas belajar. Bentuk-bentuk sikap dan perilaku yang ditunjukkan siswa yang berada pada kategori motivasi belajar tinggi untuk indikator ulet dalam menghadapi kesulitan adalah siswa sering bertanya kepada guru jika siswa tidak mengerti tentang materi pelajaran fisika yang diajarkan, siswa sering bertanya kepada teman tentang materi pelajaran fisika yang belum siswa mengerti, siswa sering tidak merasa malu jika siswa harus bertanya kepada siapapun, siswa sering belajar bersama teman untuk mengerjakan tugas atau PR fisika yang sulit, serta siswa sering mendiskusikan hal-hal yang siswa anggap sulit.

Keempat, indikator adanya informasi dari guru, Motivasi belajar fisika siswa pada indikator adanya informasi dari guru cenderung berada pada kategori sangat tinggi dengan persentase $59,80 \%$ dimana sikap siswa cenderung berada pada kategori selalu. Kelima, indikator adanya umpan balik Motivasi belajar fisika siswa pada indikator adanya umpan balik cenderung berada pada kategori tinggi dengan persentase $61,76 \%$ dimana sikap siswa cenderung berada pada kategori sering. Hasil Penelitian ini sejalan dengan yang dinyatakan oleh Hamalik (2011) dengan memberikan stimulus maka siswa akan merespon. Stimulus dan respon akan menimbulkan kebiasaan-kebiasaan otomatis pada belajar.

Keenam, indikator adanya penguatan motivasi belajar fisika siswa pada indikator adanya penguatan cenderung berada pada kategori tinggi dengan persentase $40,20 \%$ dimana sikap siswa cenderung berada pada kategori sering. Hasil penelitian ini sejalan dengan yang dinyatakan oleh Hamalik (2009) guru dituntut memberikan penguatan ekstra dan bimbingan agar siswa mau belajar lebih keras dengan penuh perhatian melaksanakan tugas-tugas belajar siswa. Bentuk-bentuk sikap dan perilaku yang ditunjukkan siswa yang berada pada kategori motivasi belajar tinggi untuk indikator adanya penguatan adalah jika guru fisika memberikan pujian terhadap pertanyaan, jawaban, tugas atau PR dan hasil ulangan siswa, semangat belajar siswa 
sering semakin meningkat; jika guru fisika membantu siswa bagaimana cara-cara menarik kesimpulan tentang materi yang sedang dibahas, maka cara-cara tersebut sering siswa gunakan dalam pembahasan materi lainnya.

Hasil penelitian ini sejalan dengan hasil penelitian Long (2013) yang menyimpulkan bahwa siswa yang memiliki motivasi tinggi akan menujukkan sikap positif dalam belajar dan guru harus mengambil langkah-langkah untuk membangkitkan motivasi belajar siswa. Hasil penelitian Bakar (2014) menyimpulkan bahwa motivasi sebagai salah satu faktor internal hanya dapat diaktifkan oleh siswa itu sendiri, tetapi stimulus dapat dimulai dari luar yang biasanya berasal dari guru. Selain itu, Emda (2017) menyimpulkan bahwa Munculnya motivasi tidak semata-mata dari diri siswa sendiri tetapi guru harus melibatkan diri untuk memotivasi belajar siswa. Motivasi belajar berfungsi mendorong siswa untuk melakukan perbuatan belajar demi pencapaian tujuan belajar. Motivasi belajar juga berfungsi sebagai pengarah dan penggerak siswa demi pencapaian tujuan belajar. Oleh sebab itu, guru perlu melakukan berbagai upaya untuk membangkitkan motivasi belajar siswa. Menurut Rohani (2010) beberapa cara yang dapat dilakukan guru untuk membangkitkan motivasi belajar siswa adalah, a) mengajar yang bervariasi; b) mengadakan pengulangan informasi; c) memberi stimulus baru, misalnya melalui pertanyaan-pertanyaan kepada siswa; d) memberi kesempatan siswa untuk menyalurkan keinginan belajarnya; e) menggunakan media dan alat bantu yang menarik perhatian siswa.

\section{SIMPULAN}

Pada dimensi motivasi intrinsik bersumber dari indikator tekun dalam mengerjakan tugas yang cenderung berada pada kategori tinggi dengan persentase $59,80 \%$ dimana sikap siswa berada pada kategori sering. Pada dimensi motivasi ekstrinsik bersumber dari indikator adanya umpan balik yang cenderung berada pada kategori tinggi dengan persentase $61,76 \%$ dimana sikap siswa berada pada kategori sering.

\section{DAFTAR PUSTAKA}

Arikunto, S. (2013). Prosedur Penelitian Suatu Pendekatan Praktik. Jakarta: Rineka Cipta

Bakar, R. (2014). The Effect of Learning Motivation on Student's Productive Competencies in Vocational High School, West Sumatra. International Journal of Asian Social Science, 4(6), 722-732. http://www.aessweb.com/pdffiles/ijass-2014-4(6)-722-732.pdf

Bloom, B., Englehart, M., Furst, E., Hill, W., \& Krathwohl, D. (1956). Taxonomy of educational objectives: The classification of educational goals. Handbook I: Cognitive domain. Toronto: Longmans Green

Cicuto, C. A. T., \& Torres, B. B. (2016). Implementing an Active Learning Environment to Influence Students' Motivation in Biochemistry. Journal of Chemical Education, 93(6), 10201026.

http://dx.doi.org/10.1021/acs.jcheme d. $5 b 00965$

Dimyati, D., \& Mudjiono, M. (2009). Belajar dan Pembelajaran. Jakarta: Rineka Cipta

Dimyati, D., \& Mudjiono, M. (2010). Belajar dan Pembelajaran. Jakarta: Rineka Cipta.

Ekawarna, E. (2009). Penelitian Tindakan Kelas. Jakarta: Gaung Persada Press

Emda, A. (2017). Kedudukan Motivasi Belajar Siswa dalam Pembelajaran. Lantanida Journal, 5(2), 172-182. http://dx.doi.org/10.22373/lj.v5i2.28 38

Febrianti, M. (2013). Pengaruh Motivasi Belajar dan Keterampilan Proses Sains Terhadap Pemahaman Konsep Fisika Siswa. Pembelajaran Fisika, 
$1(2)$,

55-66.

http://jurnal.fkip.unila.ac.id/index.p $\mathrm{hp} / \mathrm{JPF} /$ article/download/409/165

Hadis, A., \& Nurhayati B. (2014). Psikologi dalam Pendidikan. Bandung: Alfabeta

Hamalik, O. (2009). Kurikulum dan Pembelajaran. Jakarta: Bumi Aksara

Hamalik, O. (2011). Proses Belajar Mengajar. Jakarta: Bumi Aksara

Keller, J. M. (1987). Development and Use of the ARCS Model of Instructional Design. Journal of Instructional Development, $\quad 10(3), \quad 2-10$. https://doi.org/10.1007/BF02905780

Lestari, A. D. (2015). Pengaruh Tingkat Kecemasan dan Motivasi Belajar Terhadap Prestasi Belajar Fisika. Jurusan Pendidikan Fisika, 2(1), 17.

http://dx.doi.org/10.23887/jjpf.v2i1. 5547

Long, C., Ming, Z., \& Chen, L. (2013). The Study of Student Motivation on English Learning in Junior Middle School - A Case Study of No.5 Middle School in Gejiu. Canadian Center of Science and Education, 6(9), 136-145. https://doi.org/10.5539/elt.v6n9p136 Nababan, D. E. (2014). Penerapan Model Pembelajaran ARIAS Terintegratif Untuk Meningkatkan Motivasi Belajar Siswa Kelas XI MIA 1 SMA Negeri 6 Kota Jambi. Skripsi. Universitas Jambi. Jambi

Nuri, F. (2012). Pendidikan Moral dan Spiritual dalam Membangun Karakter Bangsa : Analisis Kitab Nashoihul 'Ibad Karya Syaikh Nawawi al-Bantani. Jakarta Selatan: CV. Sabrina Makmur

Rohani, A. (2010). Pengelolaan Pengajaran. Jakarta: Rineka Cipta

Sardiman, A. M. (2010). Interaksi dan Motivasi Belajar Mengajar. Jakarta: Rajawali Pers

Schunk, D. H., Pintrich, P. R., \& Meece, J. L. (2012). Motivasi dalam
Pendidikan: Teori, Penelitian, dan Aplikasi. Jakarta: Indeks

Sudijono, A. (2008). Pengantar Statistik Pendidikan. Jakarta: Rajawali Pers

Suparwoto, S. (2007). Dasar-dasar dan Proses Pembelajaran Fisika. Yogyakarta: DIPA-UNY

Ulfah, Y. (2015). Hubungan Antara Minat dan Motivasi dengan Hasil Belajar Fisika Siswa Kelas X SMAN 10 Banjarmasin. Pendidikan Fisika, 3(2), 203-213. http://dx.doi.org/10.20527/bipf.v3i2. 755

Uno, H. (2008). Teori Motivasi dan Pengukurannya. Jakarta: Bumi Aksara

Usman, H., \& Akbar, R. P. S. (2015). Pengantar Statistika. Jakarta: Bumi Aksara

Velayutham, S., Aldridge, J., \& Fraser, B. (2011). Development and Validation of an Instrument to Measure Students' Motivation and Self Regulation in Science Learning. International Journal of Science Education, 33(15), 2159-2179. https://doi.org/10.1080/09500693.20 10.541529

Widoyoko, S. E. P. (2014). Teknik Penyusunan Instrumen Penelitian. Yogyakarta: Pustaka Pelajar

Yamin, M. (2007). Kiat Membelajarkan Siswa. Jakarta: Gaung Persada Press 